Article

JENNI MILLBANK*

\title{
UNLIKELY FISSURES AND UNEASY RESONANCES: LESBIAN CO-MOTHERS, SURROGATE PARENTHOOD AND FATHERS' RIGHTS
}

\begin{abstract}
This article explores commonalities between parental claims for lesbian co-mothers and other contexts in which intention is a key aspect to family formation for (mostly) heterosexual families: in particular, surrogacy and pre-birth disputes over embryos. Through a series of case studies drawn from recent reproductive controversies, the paper uses the lens of empathy to argue for social or nongenetic modes of parenthood connecting lesbian mothers and other 'reproductive outsiders'.
\end{abstract}

KEY WORDS: assisted reproductive technology, empathy, fathers' rights, lesbian mothers, non-genetic parenthood, surrogacy.

\section{Introduction}

While many scholars have analysed the legal status of heterosexual families formed through assisted reproduction, and others have argued for reforms to specifically recognise lesbian-led families, there is relatively little engagement across and between these areas of research (see Bender 2006; Storrow 2002 for exceptions). This article explores commonalities between claims to parenthood that are not based on genetic connection, examining resonances between the position of lesbian mothers and other contexts in which intention is key to family formation for (mostly) heterosexual families; in particular surrogacy and pre-birth disputes over embryos.

Lesbian co-mothers are in a situation which parallels that of infertile men who have children through assisted reproductive technology (ART) in the sense that both have children whom they intend to raise and care for but to whom they are biologically

\footnotetext{
* Faculty of Law

University of Technology, Sydney

PO Box 123, Broadway NSW 2007

Australia

Email: jenni.millbank@uts.edu.au
} 
unrelated. ${ }^{2}$ Previously I have argued that lesbian co-mothers should be accorded full parental status in law (Millbank 2008b; Millbank 2003) using a model that approximately reflects laws in many jurisdictions granting parental status to nonbiological parents in heterosexual families formed through the use of donor gametes (based on consent to the use of an assisted conception process).3 Also common to both lesbian and heterosexual parents, if using in vitro fertilisation processes (IVF), is an experience of conception that is prolonged over months or even years - and thus increases opportunities for changes of mind and misunderstandings. There are also less tangible parallels between lesbian co-parents and fathers in their emotionally involved but physically distant relation to the gestation and birth process.

The commonalities between heterosexual families formed through surrogacy arrangements and lesbian-led families are not initially obvious. Surrogate families involve commissioning parents and a gestational mother; usually the commissioning father is also a genetic parent, less commonly the commissioning mother is also (if, for example, she has viable eggs but cannot sustain a pregnancy). While in some arrangements the gestational mother is also the genetic mother, donor eggs may be used if the commissioning mother is unable to contribute her own eggs, in which case four adults share the roles of genetic, gestational and social parents in a conception process that necessitates the use of IVF. Lesbian-led families are generally formed with the use of donor sperm. While the choice of anonymous donor or known donor may be dependent upon the accessibility of fertility services, it seems that many

\footnotetext{
2 'Co-mother' in this article refers to the non-biological parent in a lesbian couple which has planned conception together.

${ }^{3}$ Other jurisdictions extend such status only to some heterosexual couples, such as married couples, or couples conceiving through the use of state sanctioned health services or with the use of anonymous donated gametes: I do not support any such restriction.
} 
lesbians prefer to conceive in informal circumstances with an identifiable donor (who is not generally seen as a parent but will often have a family-friend or avuncular relationship, see eg. Donovan 2000; Almack 2006). Thus they, too, involve another adult in their reproductive endeavour who may at some stage assert a claim to parenthood.

Progressive and critical scholars who support recognition of lesbian and gay family forms may baulk at comparisons with surrogacy. The practice of surrogacy has been subject to acerbic feminist criticism, particularly in the United States (US), for commodifying women's reproductive labour and reinforcing a multitude of structural power imbalances (see eg. Rothman 1992). Yet there are strong thematic and legal resonances across lesbian parenting and surrogacy that deserve serious consideration. Surrogacy represents the outer edge of non-nuclear or non-autonomous reproduction for heterosexual families. Regardless of the economic power of commissioning parents, they are disempowered in the sense that they have struggled to form a family and have had to resort to (some would say, extremely) non-normative means to do so. Surrogate parents are placed in the position of lesbian families in that they need the involvement of another adult in order to conceive, they may face legal sanctions or disincentives in this process, they will often have one member of the couple who is not genetically related to their child and they are at the mercy of fertility services which may refuse to treat them. Moreover, if successful, the intended family form (and actual family function) achieved through surrogacy is generally unrecognised by law (Stuhmcke 2004; Seymour \& Magri 2004). In short, heterosexual commissioning 
parents can be seen as reproductive 'outsiders' in some ways similar to lesbian families. 4

Part I of the article sets out the context in which these issues are being raised, noting the rise of three distinct socio-legal trends: the creation of legal rights for samesex couples and parents; the increasing influence of 'fathers' rights' movements in family law; and the rise of genetic essentialism. The complex and contradictory interrelation of these trends is explored through an initial case study of two Canadian cases concerning the naming of parents on children's birth certificates. In Parts II and III of the article, resonances between the positions of non-genetic families are explored through a series of case studies drawn from recent controversies in assisted reproduction involving heterosexual couples concerning disputes over embryo use in the UK and a surrogacy arrangement in Australia. These cases raise the central difficulty of deciding who parents are when genetics are de-centred but intention is confounded by deceit or a change of mind.

In analysing these cases in Parts II and III, I engage openly with feelings of empathy and with the idea of empathy. Empathy is "a form of understanding" (Henderson 1987, 1576) which illuminates the situation of another and makes it intelligible; as such it is also a means of acquiring knowledge (D'Arms 2000, 1469). Recognising what you feel, and for whom you feel, in any given controversy is an important moment in the creation or interpretation of legal rules. Empathy, like legal reasoning itself, extends by analogy and can inform attempts to craft a legal regime

\footnotetext{
${ }^{4}$ It also appears increasingly likely that gay men may utilise surrogacy to form their own families (as opposed to jointly parenting with lesbian mothers) particularly if other avenues such as adoption remain inaccessible either through formal exclusion or practical barriers.
} 
respectful of diversity and able to recognise a broad range of family forms. I argue that empathy is a way of taking into account different experiences, perspectives and subject positions in the face of often highly abstracted legal argument, and of exploring and understanding important commonalities among otherwise heterogeneous 'reproductive outsiders'. Ultimately, I conclude that empathy is an interpretative tool that helps us to look behind singular moments of 'consent' in disputes to examine underlying legal and social structures that may deeply constrain parties' reproductive opportunities.

This does not mean that every - or any — feeling of empathy necessarily provides the 'right' answer in any of the cases discussed below. Rather, acknowledging and exploring feelings of empathy are an important part of interpretative inquiry because they draw attention to what we value, and hopefully help us to understand why this is so (see in particular Nussbaum 2001, although she prefers "compassion" to "empathy"). At the outset I acknowledge two quintessential 'values' informing my approach: first, a refusal to prioritise genetic relationships and, second, the validation of non-biological parenting relationships as an important and 'natural' part of many non-traditional family forms.5

Fathers' Rights and the Rise of the Genetic Family: Who's your Bedfellow Now?

The growth in families formed through ART has taken place against a backdrop of other social developments, including increasing diversity in family forms through the growth of single-parent households and fragmentation of biological families through

\footnotetext{
5 Julie Shapiro has written that, "Challenging the primacy of the biological link as the defining factor in parenthood was a necessary step in order for lesbians to raise children within their own families". Both co-mother recognition and the non-inclusion of sperm donors as fathers in lesbian-led families "required, and continues to require the denial of parental rights based purely on genetics" (Shapiro 2006, 598-599).
} 
divorce and separation. A significant shift away from 'traditional' family is indicated by extensive reforms in many Western countries in recent decades recognising same-sex partnerships and, more recently, granting parenting rights such as second-parent adoption to same-sex couples. This trend is dramatically at odds with a second notable movement in family law and policy through the past decade: the rise of reforms enhancing, to varying degrees, 'fathers' rights' (Graycar 2000; on trans-national trends in fathers' rights, see Collier \& Sheldon 2006). In socio-political terms these movements are plainly pulling in opposite directions. Same-sex reforms generally promote a 'reflective' or adaptive role for family law and de-centre the hetero-nuclear family as the only, or favoured, object of social policy (see Millbank 2008a), while fathers' rights claims vigorously promote the disciplining or normative role of law to keep families together, and argue for traditional gender roles as a key aspect to maintenance of the hetero-nuclear family as the foundational social institution (see Boyd 2006). In the bluntest possible contrast, lesbian mothers seek the creation and legal recognition of fatherless families, while fathers' rights advocates valorise fathers' roles as eternal and irreplaceable. Yet in legal terms, these otherwise starkly oppositional trends of same-sex recognition and fathers' rights are not entirely dissimilar. To borrow Helen Rhoades' term, both groups "yearn” for law (Rhoades 2006), focussing enormous efforts on legislative change as a path to social reform and adhering closely, even devotedly, to formal equality jurisprudence and discourse to ground their claims to "equal" treatment (Young \& Boyd 2006).

An example of the unlikely convergence of same-sex and fathers' rights equality claims is the 2006 Ontario case of Rutherford v Ontario (released as MDR v Ontario 
in the unreported version). ${ }^{6}$ In that case, four sets of lesbian parents successfully claimed that birth registry provisions excluding the co-mother were in breach of equality guarantees in the Canadian Charter of Rights and Freedoms. While the judgment is a nuanced and contextual analysis of social parenting that goes to some lengths to validate the lived experience of lesbian families, it is remarkable that it drew upon the reasoning in the Supreme Court of Canada decision of Trociuk v British Columbia.7 Trociuk concerned a father's equality claim when the mother had chosen not to 'acknowledge' him on the birth certificate; a right granted to her under the relevant birth registration scheme. Trociuk is a classic fathers' rights claim, concerning a relatively uninvolved biological father, who was not living with (and only occasionally seeing) the sons whom he wished to bear his surname. The mother, Reni Ernst, gave the children her own surname as she,

felt there was no reason why the children should bear the last name of somebody that I was not married to and had no plans to set up a life with. I saw no important connection between [his] ability to be a good father, if that is what he wanted, and the children bearing his last name (quoted in Gavigan 2006, 322).

In a brief judgment, lacking any contextual or substantive analysis of inequality, ${ }^{8}$ the Supreme Court of Canada held that the "arbitrary" exclusion of Trociuk's "participation" in the register and naming of the children was unlawful sex discrimination (Lessard 2004). Control over children's registration and naming becomes, in the formally equal and gender-neutral world of the judgment, "a

\footnotetext{
${ }^{6}$ Rutherford v Ontario (Deputy Registrar General) (2006) 270 DLR $\left(4^{\text {th }}\right)$ 90; MDR v Ontario (Deputy Registrar General) [2006] OJ No 2268.

${ }^{7}$ Trociuk v British Columbia (Attorney-General) [2003] 1 SCR 835. In particular, see Rutherford v Ontario (Deputy Registrar General) (2006) 270 DLR $\left(4^{\text {th }}\right)$ 90, para 232.

${ }^{8}$ For example, the patriarchal custom of children bearing men's names is unexamined. Moreover, the historical disadvantage faced by women in relation to their children's names is entirely reversed in the judgment which refers to this simply as gender-neutral evidence of the "significance of choosing a surname": Trociuk v British Columbia [2003] 1 SCR 835, para 18.
} 
significant mode of participation in the life of a child". 9 As Shelley Gavigan argues, "It is almost impossible to imagine a more formal, less substantive, notion of 'participation in a child's life”' $(2006,324)$.

Both Gavigan and Hester Lessard have argued that Trociuk privileges biological parenthood over social parenting and reinscribes patriarchal power relations (Gavigan 2006, 321-325; Lessard 2004). It is likely that Trociuk would prevent lesbian families in many Canadian provinces from excluding a known sperm donor from the birth registry if he wanted to be named on it, potentially both denying co-mother recognition and imposing a legal father onto a lesbian-led family. ${ }^{10}$ It is therefore somewhat unnerving to see the lesbian social parents in Rutherford frame their claim using the language of Trociuk. ${ }^{11}$ The abstract nature of precedent and language of formal equality make Trociuk and Rutherford look 'alike'. Vital differences in the respective social and legal power positions of 'parents' are elided in the judgments such that they appear as if natural progressions in a series of cases regarding children's birth certificates. While Darell Trociuk argued for the equal treatment of biological mothers and fathers regardless of any shared intention or care of children, the mothers in Rutherford argued for the equal treatment of non-biological mothers with non-biological fathers procreating in joint endeavours with biological mothers. The

\footnotetext{
${ }^{9}$ Ibid para 17 (emphasis added); see also para 16 on birth registration as "an important means of participating in the life of a child", and para 19 characterising both as "meaningful participation in a child's life".

${ }^{10}$ A donor named on the birth registry would not only take the place of a co-mother being named but could also then oppose second-parent adoption by her.

11 "Birth registration provides an important means for parents to participate in their child's life": Applicants' Factum quoted in Rutherford v Ontario (Deputy Registrar General) (2006) 270 DLR (4 $\left.4^{\text {th }}\right)$ 90, para 38.
} 
lesbian mothers can more genuinely be characterised as seeking to 'participate' rather than 'control' the child's name. ${ }^{12}$

It is worth belabouring the point that the pre-existing power positions of biological fathers and lesbian co-mothers could not be more different. As Jocelyn Elise Crowley points out, similarities in the use of equality discourse may be extremely deceptive as, while marginalised groups (such as lesbians and gay men) are "fighting for power that they never held", fathers' rights advocates are "demanding change from a position of already deeply-held power across multiple social domains" (Crowley 2006, 99, emphasis in original). Like Reni Ernst, the mothers in Rutherford were raising children in 'fatherless' or female-headed households in which actual caregiving replaced genetics as the most important basis of connection. While genetics and not caregiving is the core of fathers' rights' claims, for lesbian co-mothers it is the reverse, begging the question of how they came to be bedfellows here.

This contrast highlights a third cultural trend, which undergirds fathers' rights movements while undermining those of same-sex families: the rising notion of 'genetic truth' and its relationship to familial ideology (see eg. Dolgin 2000). Fathers' rights movements have been very successful in the past decade in drawing on both discourses of 'involved' or 'new' fatherhood and of genetic truth to implement fathers' rights claims into mainstream family law (see eg. Rhoades 2006; Smart 2006; Diduck 2007). A cultural preoccupation with genetic information has been translated into a child's right to know the 'truth' of their genetic origins (Donovan 2006). This has in turn been transformed from simply identifying progenitors into an increasingly

\footnotetext{
${ }^{12}$ One study suggests that, like Reni Ernst, many lesbian mothers see naming as primarily the responsibility of the birth mother (even if the name given is that of the co-mother or a hyphenated name) (Almack 2005).
} 
unquestioned assumption in the family law context of benefit to children from an ongoing relationship with (even previously unknown) genetic relatives. In this context 'genetic truth' may well be a stick that is increasingly used to 'beat' both lesbian mothers and heterosexual families formed with the use of donor gametes.

\section{Intended Parents and Pre-Conception Break-Ups: The Unruly Embryo} Cases

One case that provokes consideration of the connection between lesbian co-mothers and heterosexual fathers most keenly is Re R in the United Kingdom (UK). ${ }^{13}$ That dispute concerned an unmarried heterosexual couple who had sought fertility treatment initially because the man, $\mathrm{Mr} \mathrm{B}$, was infertile due to earlier treatment for testicular cancer. It became clear at some time that there was also 'a further organic reason' that the woman, Ms D, had difficulty in conceiving. Ms D underwent IVF with Mr B's support and embryos were created with the use of anonymous donor sperm. The first cycle was unsuccessful. When Ms D undertook a second transfer cycle using a stored embryo the following year, the couple had broken up, but she did not alert the hospital to this fact nor did she tell Mr B that she was continuing with treatment. This cycle was successful and after the child's birth, Mr B sought a declaration of parental responsibility and contact with the child, both of which were opposed by the mother. Although both the mother and the separate representative for the child initially agreed that $\mathrm{Mr} \mathrm{B}$ was a legal father, ${ }^{14}$ this was subsequently doubted by the Court of Appeal which returned the question for reconsideration. ${ }^{15}$ The issue of Mr B's status as a

\footnotetext{
${ }^{13}$ Re R [2001] 1 FLR 247; B and D v R [2002] 2 FLR 843; Re R [2003] 2 All ER 131 (CA); Re R (a child) [2005] 2 AC 621 (HL).

${ }^{14} \operatorname{Re}$ R [2001] 1 FLR 247.

${ }^{15}$ See B and D v R [2002] 2 FLR 843 para 2.
} 
parent was initially decided in his favour, but subsequently denied by the Court of Appeal ${ }^{16}$ and also the House of Lords. ${ }^{17}$

In the second reported judgment in the string of cases, Hedley $\mathrm{J}$ stated:

Of course in this case one must have considerable sympathy with $\mathrm{B}$. He wishes to be R's father and has responsibly fulfilled his obligations under my original order... Sympathy is, however, an unreliable aid to statutory construction. On exactly the same facts one could have a woman seeking money from a man, despite her deception, and asking for an order [declaring parental status] for that purpose. In those circumstances the sympathy would be all the other way. ${ }^{18}$

Hedley J, like many of the other judges in the cases under discussion, distrusts 'sympathy' as an emotion that merely confuses the reasoned process of statutory construction. Empathy and sympathy are related but distinct emotions, which are often referred to as though they are inter-changeable. While empathy is more akin to identification or fellow-feeling, sympathy is more closely connected to feelings of pity and as such can be a distancing or 'third-personal' feeling in a way that empathy is not (see D’Arms 2000, 1477-1479; Henderson 1987, 1579-1581). In this instance I would argue that, despite the use of the word 'sympathy', Hedley's judgment is more suggestive of an empathic response to Mr B's position.

On first reading the Re $\mathrm{R}$ cases, I empathised with $\mathrm{Mr} \mathrm{B}$, but for rather different reasons than those apparent in the judgment. Unlike Hedley $\mathrm{J}$, my concern was not that the child R would be 'deprived' of a father, or that ART could promote fatherlessness in general. ${ }^{19}$ Rather, Mr B’s claim to parenthood struck me as strongly

\footnotetext{
${ }^{16} \operatorname{Re} \mathrm{R}[2003] 2$ All ER 131 (CA).

${ }^{17} \operatorname{Re} \mathrm{R}[2005] 2$ AC 621 (HL).

${ }^{18}$ B and D v R [2002] 2 FLR 843 para 8 (emphasis added).

${ }^{19}$ B and D v R [2002] 2 FLR 843 para 9. Indeed, the potential of ART to produce 'fatherless' children for lesbian families is regarded as a benefit in my analysis.
} 
resembling that of a lesbian co-mother; his case rested on an intention to parent and participation in a joint enterprise to conceive a child rather than any genetic link. Sally Sheldon has expressed Mr B's claim as one of "emotional investment" in R (Sheldon 2005a, 356). Carol Smart has classically noted the difference between men caring "about" children while women care "for" them (Smart 1991; Smart 1995), and here Mr B's claim appears to fall squarely in the "about" camp - as he has not at any stage lived with or looked after the child (indeed through the years of litigation he had not yet met her). In this sense Smart characterises Mr B's position as akin to many traditional 'fathers' rights' claims, in which men assert the (equal) right to begin caring for children upon separation regardless of whether they provided any care prior to it (Smart 2006, 135). Yet, unlike a traditional fathers' rights claim, Mr B was not demanding "equality" with the mother, or a relationship with the child based on the perceived importance of an enduring genetic tie. In an interview quoted by Sheldon, Mr B claimed that he did not think of himself as "a champion of fathers' rights" nor had he ever been "part of a legal crusade" (Chrisafis 2001; Sheldon 2005a, 356). Eschewing "rights talk" for "care talk" (Smart 2006), Mr B added, "I have simply loved [R] from the moment I heard she was born” (quoted in Sheldon 2005a, 356).

In the same interview, $\mathrm{Mr} \mathrm{B}$ referred at length to the fact that the sperm donor was selected based on similarity to his own physical characteristics, ${ }^{20}$ a point also briefly touched on in Hedley J's judgment. ${ }^{21}$ Smart wonders at how this potential physical resemblance strengthens the man's claim to fatherhood $(2006,129)$, and it is possible to read his claim as simply reinscribing a simulacrum of the genetic tie.

\footnotetext{
${ }^{20}$ In addition, the press article commences with a description of $\mathrm{Mr} \mathrm{B}$ showing a photo of the child to the journalist and stating, "Look at the likeness. She's got my eyes and colouring, my smile, my face shape. Everyone says it. She looks just like me" (Chrisafis 2001).

${ }^{21}$ B and D v R [2002] 2 FLR 843 para 5.
} 
However, I recall that in numerous cases involving lesbian co-mothers they too assert their involvement in the process of selecting the sperm donor for their children, and frequently note that donors are chosen for characteristics similar to themselves, without the intention of 'passing' the children as their own genetic off-spring. It is perhaps possible to read the importance that parties have placed on the choice of donor in a different way, then, as evidence of their intention to jointly parent and as a manifestation of their uniquely non-biological conception process - a process in which they spent months or years imagining the child they were to have (see Jones 2005).

Sally Sheldon notes that Mr B's 'emotional investment', "does not provide a basis for legal rights, which are grounded in the more mundane and concrete realities of genetic and marital links, demonstrated intention to create a child or evidenced commitment and social parenting" (2005a, 356). I differ from Sheldon here as to whether there was in fact a "demonstrated intention" to create a child. Mr B certainly intended to create embryos in an attempt to have a child. So when an embryo was used which was 'his', why was the child not 'his'? For married couples in the UK (as in many comparable jurisdictions) it is the consent of the partner to treatment that triggers legal parenthood. ${ }^{22}$ But the Human Fertilisation and Embryology Act 1990 (UK) notably contains different provisions for married and unmarried heterosexual couples. Parental status for unmarried couples does not rest on consent; "no doubt", riposted Lord Hope, "because it was too simple". ${ }^{23}$ Instead the provisions refer to the couple

\footnotetext{
${ }^{22}$ Although in this specific instance there was no informed consent from $\mathrm{Mr} \mathrm{B}$, and indeed the space for his consent on the treatment form was left blank, many jurisdictions presume in law that a partner's consent has been given, although it can be rebutted in fact. Hale LJ notes that such would have been the approach under UK law had Mr B and Ms D been married: Re R [2003] 2 All ER 131 (CA) para 24.

${ }^{23} \operatorname{Re} \mathrm{R}[2005] 2$ AC $621(\mathrm{HL})$ para 14.
} 
being treated "together". ${ }^{24}$ Because Mr B was not being treated "together" with Ms D at the time of the embryo transfer he is not a father under UK law.

If one centred intentionality, the question to ask instead might be: having consented to the conception enterprise as a whole is there any evidence of $\mathrm{Mr}$ B's refusal of consent in this specific instance? In that case it is quite likely that $\mathrm{Mr} \mathrm{B}$ would be found to be the legal father of R.25 However, such an approach would also impose legal parenthood upon a deceived $\mathrm{Mr} \mathrm{B}$ even if he did not wish it - for example, if the mother intended, in Hale LJ's words, to "extract child support" from $\mathrm{B}^{26}$ - in which case Hedley $\mathrm{J}$ (and Hale LJ on appeal) suggest our sympathy would lie "all the other way". ${ }^{27}$ Like Hedley J, Hale LJ decries 'sympathy' in her judgment as a misleading and unstable signifier.

Hale LJ characterises the statutory provision according parental status as:

an unusual provision, conferring the relationship of parent and child on people who are related neither by blood nor marriage. Conferring such relationships is a serious matter...The rule should only apply to those cases which clearly fall within the footprint of the statutory language. ${ }^{28}$

Implicit in this passage is the place of genetics and marriage (preferably both, but if not then one in place of the other) as the essence of the legal relationship of

\footnotetext{
${ }^{24}$ Human Fertilisation and Embryology Act 1990 (UK) s 28(3). Reforms passed by the House of Lords and currently before the House of Commons continue to provide different bases for parentage of married and unmarried couples, but incorporate a clearer consent basis for unmarried couples in the "agreed fatherhood" provisions: see Human Fertilisation and Embryology Bill 2007 (UK) 120 07-08 Cls 36-38 (as amended by Committee 13 June 2008).

${ }^{25}$ This was the approach taken by Hedley $\mathrm{J}$ at first instance, characterised as a "fiction of continuing consent" by R's guardian at the House of Lords: Re R [2005] 2 AC 621 (HL). Given that a married couple would have been presumed to be consenting (see above n. 22), it is arguable that the fiction involved was instead that of treating married and unmarried infertile couples differently.

${ }^{26} \operatorname{Re} \mathrm{R}[2003] 2$ All ER 131 (CA) para 29 (emphasis added).

${ }^{27}$ B and D v R [2002] 2 FLR 843 para 8; ibid.

${ }^{28} \operatorname{Re} \mathrm{R}$ [2003] 2 All ER 131 (CA) para 20.
} 
parenthood. ${ }^{29}$ This is mirrored in a number of statements from other judgments in Re. $\mathrm{R}$, in which the relationships involved are characterised as destabilising, fictional or abnormal and for these reasons potentially harmful to the child. ${ }^{\circ}$ Yet if we believe that non-marital families and non-genetic parenting relationships are both commonplace and socially acceptable, one's sympathies - if let loose - may lead one to be rather less concerned to limit recognition of parenthood. ${ }^{31}$ Lynne Henderson argues that, "Empathy may enable the decisionmaker to see other 'right' answers, or a continuum of answers" $(1987,1653)$. In this light we might begin by asking a different question, such as: in an intention-based conception enterprise such as this one, what effect does - and should - deception have on intention? If we respect this family formation as something that was initiated as a joint endeavour leading to the creation of an embryo, disrupted by a lost opportunity to consent prior to its transfer, why could not Mr B be provided by the court with the reinstatement of consent in the form of a choice to conclusively affirm or deny paternity at some later point?

But then, what of the mendacious Ms D? We have little discussion of her intentions, or her choices, and little or no opportunity to empathise with her position. Hedley $\mathrm{J}$ found "Ms D a wholly unreliable witness whose evidence and memory were at every turn coloured by her determination to have a child and to exclude Mr B from her life."32 The judgments are pithily harsh on D's actions. Ms D "misled" the hospital

\footnotetext{
${ }^{29}$ Lord Hope makes a very similar statement: Re R [2005] 2 AC 621 (HL) para 6.

${ }^{30}$ See eg. Ibid Lord Walker paras 35, 42; Re R [2001] 1 FLR 247 para 6 Hedley J refers to the three men who are potential biological and social fathers to the child as a "warning to consider the implications for any child so conceived as well as regard to the rights of prospective parents".

${ }^{31}$ Indeed my sympathies alert me to the many intra-lesbian cases in which courts have refused to even hear the claim of a non-biological mother for contact with her child, no matter the merits of the case, because 'non-parent' claims are not expressly authorised by legislation, discussed in Millbank, 2008b.

${ }^{32} \operatorname{Re} \mathrm{R}[2001] 1$ FLR 247 para 11.
} 
about her relationship with $\mathrm{Mr} \mathrm{B}$, kept the treatment and pregnancy secret from $\mathrm{Mr} \mathrm{B}$ and initially also lied in evidence about her dealings with the hospital. The court at first instance held that Ms D made unfounded allegations about Mr B's behaviour towards her when opposing his application for contact and parental responsibility, including allegations of "domestic violence and non-consensual sex" as well as harassment by telephone. As the appeals focus on parental status (limited indirect contact was ordered at first instance and the parental responsibility issue was adjourned), these issues are entirely erased in the later judgments and we are left only with Mr B's earnest wish to be a father. Yet feminist research suggests that domestic violence is both under-reported and under-recognised in family law decision-making, leading us to question whether every "unfounded" allegation of domestic violence is actually false (Kaye, Stubbs \& Tolmie 2003; Kaspiew 2005). The erasure of the possibility of violence, or of any rational reasons for D's seeking to "exclude" Mr B begins to trouble me.

This generates other questions about Ms D, in particular why she lied to the hospital and why she withheld the information that she was undergoing treatment from Mr B. These facts are not 'just' facts: they arise in the context of UK legislation on fertility treatment which is prescriptive in nature and discriminatory in application. The Act provides that "a woman shall not be provided with treatment services unless account has been taken of the welfare of any child who may be born as a result of the treatment (including the need of that child for a father)."33 Until 2001 this provision was interpreted by most providers to exclude single women and lesbians from fertility

\footnotetext{
${ }^{33}$ Human Fertilisation and Embryology Act 1990 (UK) s 13(5). Reforms currently before parliament replace 'father' with 'supportive parenting': Human Fertilisation and Embryology Bill $2007 \mathrm{cl}$ 14(2).
} 
treatment altogether.34 Even though increasing numbers of lesbians and single women have accessed fertility services in the UK in recent years as the legislation has been interpreted more liberally,35 they may still be lawfully excluded by any provider, and remain far less likely to be accepted into publicly funded services than heterosexual couples. ${ }^{36}$

If Ms D had told the hospital her relationship with Mr B had broken down they would have stopped treatment and required her to go through a new round of counselling and assessment.37 Even if Mr B had been able to vary the terms of his consent 38 and had consented to D's use of the embryo, treatment could have been refused because of the clinic's interpretation of the potential child's 'need' for a father. The most likely course is that Ms D would have had to apply for permission to undergo another full cycle of IVF to generate embryos with her new partner. Given that this was

\footnotetext{
${ }^{34}$ Almack 2005 at 4 notes a 2001 survey of UK clinics by a same-sex parents group which found that only $25 \%$ of clinics reported that they accepted lesbian clients.

${ }^{35}$ Human Fertilisation and Embryology Agency (HFEA), 'Figures for Treatment of Single Women and Lesbian Couples 2000-2005

<http://www.hfea.gov.uk/cps/HFEA/files/Figures_for_treatment_of_single_women_and_lesbian_couples_20002005.pdf > (accessed 10 July 2008). See reference to the 'relaxation' of the 'need for a father' standard since 2001: “'Bio-panic' sees Twice as Many Single Women Try for Babies” The Telegraph (UK), 9 October 2006. The 2005 HFEA Guidelines on s13(5) provide that, "Where the child will have no legal father, the treatment centre is expected to assess the prospective mother's ability to meet the child's/children's needs and the ability of other persons within the family or social circle willing to share responsibility for those needs': HFEA, Revised Guidelines, Welfare of the Child and Information Sections under the Code of Practice, 2005, Cl 3.9 http://www.hfea.gov.uk/en/490.html accessed 10 July 2008.

${ }^{36}$ HFEA notes that access for single women and same-sex couples will "vary from clinic to clinic": HFEA Guide to Infertility 07/08, online at <http://www.hfea.gov.uk/docs/Guide2.pdf> p. 13 (accessed 10 July 2008). There remains widespread confusion among providers regarding 'social criteria', such as relationship status, in providing treatment: see Linda Harrison, 'A Survey Measuring the Impact of NICE Guidelines 11: Fertility - Assessment and Treatment for People with Fertility Problems' (2005) p. 12. The British Fertility Society concluded that there is considerable disparity in the application of social criteria and resulting inequity of access to publicly funded treatment: see R Kennedy, C Kingsland et al, 'Implementation of the NICE Guideline - Recommendations from the British Fertility Society for National Criteria for NHS Funding of Assisted Conception' (2006) 9(3) Human Fertility 181.

${ }^{37}$ See Re R [2003] 2 All ER 131 (CA) para 25.

38 It is questionable whether this was contemplated under the 1990 Act, but is possible under amendments currently before parliament: see Human Fertilisation and Embryology Bill 2007 cl 4, cl 37, Sch 3.
} 
a new relationship, they may not have been approved. Even if treatment was approved it would have entailed invasive medical treatment and lengthy delays. The National Health Service (NHS) only covers the full cost of between one and three cycles of IVF for women under 40,39 with a waiting list for treatment (depending on region) that may be years long, and indeed is longer if donor sperm is required.40 The case reports reveal that Ms D and Mr B were first referred to the clinic in 1992, they waited two years before seeing a specialist, and then waited a further two years from the time of seeing the specialist (during which time they undertook three counselling sessions) before approval for treatment was finally granted. There was then a further delay of almost a year before treatment actually commenced in 1998. Looked at in another way, if the health system was better resourced or more efficient, $\mathrm{R}$ could have been born long before B and D broke up.

We are never told how old Ms D was at the time she conceived, nor what the source of her difficulty with conceiving was, but a fair inference may be that her reproductive choices were severely constrained. This embryo may have been D's best hope of having a child, or it may have been her only hope. In this light, more than six years after first seeking assistance in conceiving, with health services that were limited, slow and discriminatory, a possibly violent ex-partner, a new partner who would likely not qualify for treatment, and a choice between a simple transfer cycle or

\footnotetext{
${ }^{39}$ HFEA Guide supra note 36 at 10 . The Guide lists the cost of privately funded IVF as between $£ 4000$ and $£ 8000$, ibid.

${ }^{40}$ See eg. a two year waiting list in North Yorkshire that was then subject to a suspension of treatment for 12-18 months: Lucy Stephens. IVF Blow for the Childless. The York Press, 30 April 2007, http://www.yorkpress.co.uk/news/campaigns/doctor/display.var.1364376.0.ivf_blow_for_the_childless.php (accessed 10 July 2008). Waiting time of seven months in Glasgow contrasts with three years in the Lothians: Russell Jackson. IVF Waiting List Grows to Three Years. The Scotsman, 8 May 2007, http://news.scotsman.com/topics.cfm?tid=459\&id=712182007 (accessed 10 July 2008).
} 
an invasive full cycle of IVF, I feel rather more understanding of D's decision to lie in using 'her' embryo than on first reading the judgments.

I notice that I shifted here from referring to the embryo that created $\mathrm{R}$ as 'his' embryo to labelling it 'her' embryo. In the first draft this was an unconscious shift, and in edits I then changed it to 'the' or 'their' embryo in an attempt to signal neutrality. Writing a third draft I felt this was an essentially dishonest disclaiming of my own thesis, so I put the possessive forms back in (but within quotation marks this time, to demonstrate that I had noticed). I began by empathising with $\mathrm{Mr}$ B and ended by empathising with Ms D. This shift alerts us to what Henderson calls the possibility of "decisional paralysis" if one empathises with both of the affected parties in a dispute (1987, 1653). Can the embryo be both 'his' and 'hers'? This question is brought out most acutely if we consider: what if Mr B had been consulted and refused his consent? Given the constraints on Ms D's reproductive choices just outlined, I am not at all convinced that $\mathrm{Mr} \mathrm{B}$ should have the power to prevent Ms D from using the embryo.

Empathy now does seem an extremely unreliable aid to interpretation, as this imagined fact scenario leads to an outcome of unilateral use of the embryo for Ms D that appears utterly inconsistent with my earlier position that Mr B should have the choice of fatherhood and that such choice is not contingent on genetic connection. However, this is not necessarily so, as the conclusion of inconsistency presumes that consent to conception attempts and consent to legal parenthood are inextricably intertwined. Yet it is possible to frame rules about the use of gametes and the parentage of children that differ, reflecting the fact that adults may have very different relationships with gametes, embryos and foetuses than with children. It is difficult but not impossible to contend that if men in IVF conception endeavours withdraw their 
consent after the creation of embryos the effect should be that they are not a parent in law rather than granting an absolute or inevitable veto over use of the embryo. This should not be a specific exception for Mr B because he is a non-genetic parent, but a more general rule premised on the far greater physical toll faced by women undergoing IVF and the (usually) more limited reproductive opportunities available to them. I would apply the same principles of consent to men who do have a genetic connection to the embryo as well as those who don't, and to lesbian co-mothers as well. Empathy, then, need not lead to paralysis; it may instead draw us away from the binary positions that adversarial decision-making engenders and open up a more complex series of considerations and potential outcomes.

The case brought by Natalie Evans, culminating in an appeal in 2007 to the Grand Chamber of the European Court of Human Rights raises an extreme example of a male partner's 'veto' power in IVF which brought forth strong emotional reactions in both the public and the judiciary.41 In that case Natalie Evans was diagnosed with slow-growing ovarian tumours and advised that she could undergo one cycle of egg harvesting prior to surgery to remove her ovaries and fallopian tubes, which would allow her to undertake IVF later in life. Unlike the unmarried couple in Re R, Evans and her partner, Howard Johnston, were rushed through assessment and treatment because of her illness: she was told of her diagnosis, counselled and had signed the consent forms for fertility treatment in the space of an hour. ${ }^{42}$ Evans asked if her eggs could be frozen without first fertilising them with Johnston's sperm (a highly experimental treatment at that time) and was told that the clinic was only able to

\footnotetext{
41 See eg. "Your views" at the conclusion of "Women Lose Embryo Battle" BBC News 1 October 2003 , http://news.bbc.co.uk/2/hi/health/3151762.stm (accessed 10 July 2008); "Medical Expert Reaction” BBC News 10 April 2007, http://news.bbc.co.uk/2/hi/health/6541737.stm (accessed 10 July 2008).

${ }^{42}$ Evans v Amicus Healthcare [2003] All ER 903 at paras 46-49.
} 
freeze embryos not eggs. Johnston urged Evans "not to be negative", reassured her that he wanted to have children with her, and the couple signed consents to be treated together. 43 The procedure went ahead some weeks later in which six embryos using the gametes of both partners were ultimately created and frozen. Evans and Johnston broke up six months later and two months after the break-up Johnston informed the clinic of this fact, indicating that he wished the embryos to be destroyed. Evans instituted proceedings in the Family Division of the High Court seeking, inter alia, an injunction to restore Johnston's consent, a declaration of incompatibility of various sections of the Human Fertilisation and Embryology Act 1990 with the Human Rights Act 1998 due to interference with her rights to privacy and family life as well as the right to found a family,44 and a claim to promissory estoppel. Evans was unsuccessful on all counts and remained so on appeal at the Court of Appeal45 and in her claim against the United Kingdom in the European Court of Human Rights ${ }^{6}$ and Grand Chamber47 (although there were two dissenting judges in the European Court and four in the Grand Chamber).

As in the case of Re $\mathrm{R}$, the discriminatory child 'welfare' provision in UK legislation and practice has a lot to answer for in Evans (Sheldon 2004). Clinic staff attested that if Ms Evans had insisted on pursuing fertility options that did not leave her dependent on Mr Johnston's participation and consent (and given the ultimate outcome of the case, one must say, control) then they would probably not have treated

\footnotetext{
${ }^{43}$ Id para 58.

${ }^{44}$ Evans was joined in the first case by Lorraine Hadley, whose husband had also withdrawn consent to the use of their embryos upon their relationship breakdown. Hadley did not appeal.

${ }^{45}$ Evans v Amicus Healthcare [2004] 3 All ER 1025. Evans was refused leave to appeal to the House of Lords.

${ }^{46}$ Evans v United Kingdom [2006] 1 FCR 585 (ECtH.R).

${ }^{47}$ Evans v United Kingdom [2007] 2 FCR 5 (Grand Chamber).
} 
her at all, based on their "perception of the suitability and appropriateness of IVF treatment for the couple since the welfare of any potential child or children from such treatment is always our paramount concern".48 In a non-discriminatory program Evans could have had some or all of her eggs fertilised with donor sperm (or even frozen unfertilised, although it was at that stage a highly experimental procedure49), to hedge her bets as it were. However in the UK regime as it then stood these options would not only have been refused but likely led to a denial of treatment altogether. While there is not scope in this article to explore all of the arguments made by Evans, the lack of judicial attention to the relationship between the discriminatory legislative provisions and the loss of Evan's reproductive freedom is really regrettable. The issue is not just the question that the courts focus on, which is that Johnston denied his half of bilateral consent required by the legislation; rather, the deeper rights infringement was that the legislation forced Evans into the position of being solely dependent upon his consent in the first place.

As in the Re R case, sympathy was both openly acknowledged and clearly distrusted throughout the multiple Evans judgments. In the Family Division, Wall $\mathrm{J}$ commences his summary of the disputed facts about the decision to generate embryos, "by recording my sympathy for Ms Evans both in relation to her medical condition and to the events of that day" ${ }^{\circ}$ and concludes his assessment of the right to privacy and family life with "I cannot allow my sympathy for Ms Evan's position to outweigh my

\footnotetext{
${ }^{48}$ Evans v Amicus Healthcare [2003] All ER 903 para 53, see also para 55.

49 The first baby born in the UK from a frozen egg was in May 2002: see HFEA, 'Freezing and Storing Your Eggs' Factsheet November 2006. The practice is increasing: see 'Career Women Must Not Have Eggs Frozen to Delay Family' The Times 18 October 2007.

${ }^{50}$ Id at para 44.
} 
respect for the scheme which Parliament has put in place" ${ }^{51}$ If anything, the judges of the Court of Appeal are more open in acknowledging their emotional responses to the case. The majority judges, Thorpe and Sedley LJJ, preface a number of statements of facts with "sadly" and describe the situation as a "tragedy" for Ms Evans, while Arden LJ's concurring judgment characterises the issues as "emotive" and the experience of infertility as causing "great personal distress".52 Yet the majority conclude their discussion of the right to privacy and family life with the finding that the "sympathy and concern which anyone must feel for Ms Evans is not enough to render the legislative scheme ...disproportionate”.53

The majority in the European Court of Human Rights54 and the Grand Chamber55 also expressed "great sympathy" for Evans. Yet in all of the judgments sympathy is swiftly and completely overwhelmed by the discourse of formal equality. Both Evans and Johnston have a genetic tie to the embryos in dispute, Evans wants a genetically related child while Johnston does not; this is transformed into an "equal" claim to the embryos involving an equal right to consent to use and an equal right to withdraw consent to use and determine their destruction.56 The deployment of equality in the judgments is profoundly gender-blind and is informed by a series of completely inapplicable reproductive analogies and reversals that are used to 'prove' how equal the treatment of Evans and Johnston is in law (see Lind 2006 and Sheldon

\footnotetext{
${ }^{51}$ Id at para 260. A postscript to the judgments repeats the expression of sympathy at para 317.

${ }^{52}$ Evans v Amicus Healthcare [2004] 3 All ER 1025 paras 80, 81.

${ }^{53}$ Evans v Amicus Healthcare [2004] 3 All ER 1025 at para 69.

${ }^{54}$ Evans v United Kingdom [2006] 1 FCR. 585 (ECtHR) para 67.

${ }^{55}$ Evans v United Kingdom [2007] 2 FCR. 5 (Grand Chamber) para 90.

${ }^{56}$ Equality of treatment was raised at first instance by the Secretary of State: Evans v Amicus Healthcare [2003] All ER 903 paras 237, 238, 240 and by Johnston and Hadley's counsel in paras 246, 247.
} 
2004). In particular, the judgment in the Family Division deflects Evan's arguments on her right to privacy and family life by framing her claim as one which seeks to "impose" parenthood on Johnston and thrice using a hypothetical reversal of Johnston seeking to "impose" parenthood onto Ms Evans through a forced implantation of the embryo and forced pregnancy.57 In the most simplistic of syllogisms the obvious unacceptability of coerced pregnancy for women conclusively proves the unacceptability of using embryos without men's consent. 58 The equality implications of this analogy were repeated or referred to with approval on a number of occasions by the appeal courts. 59

Yet as Craig Lind has argued, it is not at all an uncommon experience for men to become parents against their will, nor does this experience necessarily impact upon their lives greatly (Lind 2006; Lind 2003). Moreover, even in extreme cases of deceit and impaired consent, Sally Sheldon notes the law has itself imposed parental status upon fathers (Sheldon 2001). Johnston's position in the case draws on both genetic essentialism and on modes of 'involved' New Fatherhood that are closely connected to

\footnotetext{
${ }^{57} \mathrm{Eg}$. id at para 184 (emphasis added):

the right to respect for private life applies equally to both Mr Johnston and Mr Hadley. An unfettered right on the claimant's part to have the embryos transferred into them would, by parity of reasoning, constitute an interference with respect of the men's art 8 rights, in the same way that any attempt on their part to insist that the claimants have the embryos transferred into them against their will would undoubtedly constitute an interference both with the claimants' right to autonomy over their own bodies, and with respect for their private lives.
}

This analogy is repeated at para 251 , and extended to include the man having testicular cancer in para 319 .

\footnotetext{
${ }^{58}$ The final example was prefaced with the remark that it "is not difficult to reverse the dilemma": id at para 319. In fact, it is extremely difficult to reverse the dilemma given that if Mr Johnston had had cancer he could easily have frozen his semen independently and would not have needed to create embryos. Moreover, Craig Lind notes the legislation required clinics providing any treatment to women to consider the child's "need for a father" but did not have any such requirement to consider mothers if men were seeking treatment (2006). Further, if embryos were created, 'reversing' the dilemma does not lead inexorably to forced pregnancy; it could include options such as the use of embryos with a new partner, or with a surrogate.

${ }^{59}$ See eg. Evans v Amicus Healthcare [2004] 3 All ER 1025 Arden LJ concurring at para 111 "Motherhood could surely not be forced on Ms Evans and likewise fatherhood cannot be forced on Mr Johnston"; Evans v United Kingdom [2006] 1 FCR 585 (E.Ct.H.R.) para 66. The analogy was disapproved by the dissenting judges in Evans v United Kingdom [2007] 2 FCR 5 (Grand Chamber) para 14.
} 
fathers' rights discourse.60 The Family Division holds that Johnston should not be the biological father of a child "with whom [he] could not enjoy any form of natural paternal relationship". ${ }^{61}$ (Although, as I argue in Re D, the court could allow him a choice at this later point, and indeed Evan's position was that Johnston could "play as little or as great a role as he wished". ${ }^{62}$ In this light, much stress falls on the word "natural"). Implicitly, references in the judgments to the potential child's interests rest on the assumed harm of being raised fatherless. ${ }^{63}$ While not in any way endorsing Evans' 'right to life' arguments on behalf of the embryos, ${ }^{64}$ I note that the figure of the potential child appears in a deeply paradoxical manner, her imagined welfare demanding only her non-existence.

Commentators on the US embryo dispute cases have noted that the "imposition" on men in these circumstances need not involve either legal or social parenthood (Cahn 2002; Waldman 2004), and so could be no more than knowing that there is, somewhere in the world, a person genetically connected to them. Naomi Cahn has argued that,

\footnotetext{
60 'Involvement' for men in parenting may also bear some relation to 'control'. It is interesting that Johnston's recollection of the consent process included the following observation: "I was reassured by the fact that I would still maintain the same control regarding this decision as I would had these unfortunate events not occurred": Evans v Amicus Healthcare [2003] All ER 903 at para 49.

${ }^{61}$ Id at para 319. The court also finds that Johnston would be financially liable to support the child and could not be released from this obligation by Evans. Given the findings on the requirement of 'treatment together' to accord paternity in Re R discussed above, this seems erroneous as they would not be treated 'together' at the time of transfer. Alternately, Evans could surely have entered into consent orders for a zero assessment under the Child Support Act 1991 (UK). Amendments before parliament, if passed, make it possible for a man to vary his consent to allow embryo transfer without agreeing to become a legal parent as a consequence, see above note 38 .

${ }^{62}$ Evans v United Kingdom [2006] 1 FCR 585 (ECtHR) para 52.

${ }^{63}$ Alternately, the harm is in being 'unwanted' by her father which, even if it persisted and were made known to her, is still not an uncommon experience.

${ }^{64}$ See Evans v Amicus Healthcare [2003] All ER 903 paras. 174-179. Evans was refused leave to argue this point on appeal: Evans v Amicus Healthcare [2004] 3 All ER 1025 para 19.
} 
basing the right not to procreate on a fear of having genetically related offspring makes genes the central and defining aspect of the parent-child relationship. This approach misstates the power of genes and biological parenthood and privileges one person's genetic connection over another's (Cahn 2002, 586-587).

The extremity, the clear falsity and the repetition of the forced pregnancy analogy in the judgments suggest that although the judges are expressing "sympathy" for Evans, it is arguably Johnston with whom they actually empathise. The powerfully emotive example of a forcibly impregnated female body65 is conjured up for the sole purpose of demonstrating an otherwise invisible, even unintelligible (or at least insignificant in the sense of being both common-place and non-intrusive) harm to men: genetic children they didn't actively choose to have. It is men's position we must feel for here, even if we have to use women's bodies to do it. I claim this is an example of what Henderson labels "unreflective empathy", where decision-makers connect with the position of parties most like their own privileged position without realising or admitting that they are doing so, and therefore replicate patterns of covert discrimination or entrenched inequalities that remain "unseen" by them (Henderson $1987,1584-1586,1652)$. This is not to say that empathy is therefore unhelpful, rather it is a caution that - like other forms of reasoning - it can be used in lazy ways. Henderson argues that "selective" or "unreflective" empathy masks rather than reveals moral choice (1652), and the simplistic embrace of formal equality discourse (facilitated by the use of false analogies) in the Evans judgments bears this out powerfully.

I believe that a reflective use of empathy in this case would help move beyond the binary of forced parenthood/deprivation of children set up in the judgments in

\footnotetext{
${ }^{65}$ Present in the collective consciousness following the attempted genocide of Muslims in the Balkans war, inter alia, through rape and forced pregnancies.
} 
which each party's equal and opposite interest in the embryos' use/destruction must balance each other out because of the over-riding 'good' of equality. Empathy should lead us to a far more contextual analysis both of the value of each party's interest or investment in the embryos and of the impact on each of them of their use or destruction. In terms of both interest and impact, Evans' claim is more significant than Johnston's, so she should be able to use the embryos.66 Consistently with my arguments regarding Re R, if a child resulted, Johnston could then be given a choice as to whether or not he is a legal parent.

Craig Lind notes that Evans' position, like that of Johnston, reflects an "obsession with genetic parenthood" and he contends that judicial and public expressions of sympathy for Evans were "the result of our collective understating of the appropriateness of the desire of all would-be parents to have their own children" (Lind 2006, 586). Here I support Evan's claim in spite of, rather than because of, genetics. Evans had six viable embryos in storage; she did not have - and would likely have found it very difficult, if not impossible, to engage - both an egg donor and a sperm donor for future conception efforts, ${ }^{67}$ even if she could have found a clinic that would treat her in such circumstances. Nor is it likely as a single woman that Evans would be able to adopt a child. Evan's predicament did not rest, then, solely on her desire to have a genetically related child, but rather, like many lesbian mothers, came

\footnotetext{
66 If this remedy seems too extreme, for example, if empathy for Johnston were to restrain one from retrospectively over-ruling the terms of the consent form he signed, other outcomes are still possible. For example, one could have found that the "need for a father" provision of the Human Fertilisation and Embryology Act 1990 (UK) or that the consent forms in use under the Act as it then stood were incompatible with the Human Rights Act 1998 (UK) so that in later cases women would be availed of a wider range of reproductive options at the outset and granted greater autonomy over the use of embryos once created.

${ }^{67}$ Even in private clinics in the UK, donor gametes are in extremely short supply: see 'Worry over sperm donor shortage', BBC News 31 July 2006 <http://news.bbc.co.uk/2/hi/health/5230890.stm> ; 'IVF donor sperm shortage revealed', BBC News 13 September 2006 <http://news.bbc.co.uk/2/hi/health/5341982.stm>; 'Pay egg donors say fertility specialists' The Independent 26 October 2006 <http://news.independent.co.uk/health/article1930121.ece> (all accessed 10 July 2008).
} 
about as a result of legislation and social policy discriminating against intentionally fatherless families.

\section{Surrogacy}

Both commissioning parents and lesbian mothers defy 'naturalness' and displace the primacy of bio-genetic ties in favour of intended relationships in family formation. In the US this resonance between surrogacy and lesbian-led families has been most clearly articulated in scholarly consideration of the central role of intention in defining parental status of families formed through assisted reproduction (Storrow 2002; Bender 2006). The development of an "intended parent" doctrine by the Californian Supreme Court in the surrogacy dispute of Johnson v Calvert ${ }^{68}$ and extension of it by the California Court of Appeal to both non-biological commissioning parents in the child support dispute of Buzzanca69 has highlighted the issue even more strongly in the US context. When the leading US lesbian rights organisation, the National Center for Lesbian Rights (NCLR), published a 'Model Brief' for co-mother recognition in 2000, it drew extensively on Buzzanca and sought to extend principles of intention drawn from surrogacy disputes (Minter \& Kendall 2000). The NCLR submissions in the ground-breaking lesbian co-mother recognition case Elisa $\mathrm{B}$ also took this approach. ${ }^{70}$

\footnotetext{
${ }^{68}$ Johnson v Calvert, 851 P2d 776 (1993).

${ }^{69}$ Buzzanca v Buzzanca 72 Cal Rptr 2d 280 (1998).

${ }^{70}$ Elisa B v Superior Court of El Dorado County, 37 Cal 4th 108 (2005). See eg. NCLR Opening Brief and Reply Brief for Emily B, available at http://www.nclrights.org/site/DocServer/elisab_nclrbrief_020805.pdf?docID=761. Accessed 10 July 2008.
} 
Like the Rutherford mothers drawing on Trociuk, the Elisa B claim causes me unease as the use of abstract principles about the role of 'intention' drawn from surrogacy case law elides important differences in factual context. Many US surrogacy cases concern disputes between commissioning parents and gestational mothers who have changed their minds about relinquishing the child. "Intention" in these cases, then, is about the unchanged intention of the commissioning parents versus the changed intention of the 'surrogate' or gestational mother. Centring intention in surrogacy disputes may thus mean prioritising pre-conception intention over postbirth intention, and privileging the commissioning parents' intentions over the reproductive labour of the gestational mother. Centring intention in lesbian families to gain recognition of the co-mother from the State for intact lesbian families, or to assert parental status for the co-mother in the context of intra-lesbian disputes about children, is not directly comparable to surrogacy disputes because it does not entail depriving the birth mother of parental status against her wishes.

In lesbian-led families, the closest analogy may be in cases where the intended family was one involving two mothers who are primary carers and an uninvolved (or 'family friend') role for a known sperm donor who changes his mind post-birth and seeks to be an involved parent. An increasing number of such disputes are arising over very young babies, in which case there is little or no pre-existing pattern of contact and the donor's claims rest firmly on biological connection. ${ }^{71}$ In these cases, centring preconception intention would exclude the sperm donor from parental status (and from seeking to establish a parental relationship) regardless of his genetic connection to the child. Indeed, Nancy Polikoff has argued that women should be able to enter into

\footnotetext{
${ }^{71}$ See eg. Re Patrick (2002) FLC 93-096; Xv Y (2002) SLT (Sh Ct) 161; H and J \& D [2006] FamCA 1398; McD v L [2007] IESC 28; Mc D v L \& Anor [2008] IEHC 96.
} 
binding contracts with known sperm donors to achieve exactly this end (Polikoff 1996; 2000). Yet it is hard to imagine lesbian and feminist scholars arguing in favour of agreements binding surrogate mothers. ${ }^{2}$ While it is important to acknowledge that there may be a commonality in the experience between surrogates and donors engaging in the reproductive endeavours of others - such as unexpected love for the child leading to feelings of regret, grief or guilt (see eg. Dempsey 2004, who argues that some gay sperm donors had an experience closer to relinquishment than gamete donation) - a gender-blind analogy fails to take into account the massive differential in reproductive labour between a sperm donor and a gestational mother.

All of this suggests that one must be very careful to be truly fact-sensitive in drawing analogies or extending principles in the context of surrogacy. In particular, the unique position of the gestational mother must be acknowledged, including the value of her reproductive labour, her relationship with the foetus and the importance of her bodily autonomy (Bender 2006). Even the most basic empathic response tells us that gestational mothers should not be forced by law to relinquish children any more than they should be prevented by law from having abortions (Storrow 2002). This means privileging the intentions of the gestational mother over other participants by allowing her to change her mind through the pregnancy and for some time afterwards (although both a sense of fairness to the commissioning parents and a best interests approach to the child's attachments would suggest not indefinitely). Privileging the gestational mother's intentions (but not those of a sperm donor) accords with the fundamental values laid out at the opening of this article in that it does not prioritise genetics, applying regardless of whether the commissioning parents or surrogate are

\footnotetext{
${ }^{72}$ For an argument that intent-based or functional parenting recognition for lesbian parents cannot be applied to gay male parents conceiving through surrogacy, see Appleton 2006.
} 
genetic parents, 73 and it does value caregiving relationships (in this case to the foetus) again regardless of genetic connection.

These considerations mean that it is vital to distinguish between the legal issues of parentage in surrogacy arrangements where there is no dispute between the participants and those that involve competing claims to parentage and residence of the child when the adults are in dispute. In harmonious surrogacy arrangements the commissioning parents are the social parents of the child but their legal and genetic relationships do not 'match'. One or both may be genetic parents, or neither may be, but in each situation both commissioning parents will likely lack legal status. In many jurisdictions the legal parents of a child born through any form of assisted conception are the gestational mother and her consenting male partner (eg. in Australian states, see Millbank 2006). A number of cases reveal that commissioning fathers who are also genetic fathers list themselves on the birth certificate regardless of such provisions, 74 and so may be able to 'pass' if their status is unquestioned, whereas the commissioning mother is always excluded. Co-mothers in lesbian-led families are likewise intended and functioning parents who are (largely) unrecognised in law, and so I argue that empathy should lead lesbian mothers to support legal status for commissioning parents in harmonious surrogacy arrangements.

Validating the intended family form and valuing the caring relationship of the commissioning parents could be accomplished by creating a legal regime allowing for

\footnotetext{
${ }^{73}$ Unlike many US cases where the success of the commissioning mother's claim has often hinged on whether or not she is the genetic mother: see Storrow, 2002.

${ }^{74}$ See eg. Re Evelyn (1998) FLC 92-807; PJ v Department of Community Services [1999] NSWSC 340; King and Tamsin [2008] FamCA 309.
} 
the consensual transfer of parental status between the adults.75 Privileging the intention of the gestational mother requires that any transfer of status take place with her informed consent in a period after birth. ${ }^{6}$ Legislation allowing for the transfer of parental status to the commissioning parents of a child between six weeks and six months old by court order was passed in 1994 in both the UK77 and the Australian Capital Territory (ACT). ${ }^{78}$ Similar legislation before parliament in Western Australia in 2008 will, if passed, allow for transfer of parental status between 28 days and one year after the birth. ${ }^{79}$ However, unlike the Western Australian proposal, the ACT and UK regimes remain inadequate because they continue to prioritise genetic relationships: parties are only eligible to transfer status if one of the commissioning parents is a genetic parent and the gestational mother is not. ${ }^{80}$ So it is not intended parents as such, but rather a genetic parent and their partner who are able to have parentage transferred to them. Moreover, the original UK provisions were only available to married commissioning parents, further limiting the scope to a genetic parent and

\footnotetext{
${ }^{75}$ Similarly, when sperm donors are intended to be parents in multi-parent lesbian and gay family forms their role could be accommodated by a post-birth process that entails a sharing of parental status rather than transfer of status: see Victorian Law Reform Commission. 2005. Assisted Reproductive Technologies and Adoption, Position Paper Two: Parentage interim recommendation 13-4. However, note that this proposal was dropped in the final report on the basis that it was unwieldy and did not meet a demonstrated need by gay and lesbian families because of the generally non-residential role of biological fathers: Victorian Law Reform Commission. 2007. Assisted Reproductive Technology \& Adoption, Final Report.

${ }^{76}$ Pre-birth transfers of status, which are permitted in some US jurisdictions, would breach this principle: see Snyder \& Byrn 2005.

${ }^{77}$ Human Fertilisation and Embryology Act 1990 (UK) s 30, discussed in Stuhmcke 2004, 21.

${ }^{78}$ The Substitute Parent Agreement Act 1994 (ACT) was replaced by Parentage Act 2004 (ACT) Div 2.5.

${ }^{79}$ Surrogacy Bill 2007 (WA), passed by the lower house on 26 June 2008 and currently before the upper house. For current status see <http://www.parliament.wa.gov.au/web/newwebparl.nsf/iframewebpages/Bills+-+Current>. accessed 10 July 2008. Both Australian regimes require the consent of the gestational mother's partner including a female partner.

${ }^{80}$ Parentage Act 2004 (ACT) s 24.
} 
legal spouse. ${ }^{81}$ A recognition system which truly valued the caregiving relationship of intended parents with the children they raise would not be subject to such limitations.

In situations where gestational mothers and commissioning parents are in conflict, the question of legal status is far more complex than in harmonious arrangements; parental status, parental responsibility, residence and contact may all be in issue between multiple adults, and are all potentially severable. Naomi Cahn has noted in the US context that, "[w]hile courts claim that they can separate the decision on parentage from that on custody, their decisions show that they do not" (Cahn 1991, 1). In contrast to the US, courts in Britain and Australia have applied the child's best interests test and shown themselves more inclined to fragment the legal components of parenthood in situations such as surrogacy disputes and ART mix-ups (Sheldon 2005b), where there are multiple contenders for parental status. The sole reported surrogacy dispute in Australian law, Re Evelyn, exemplifies this difference in approach with the court simply side-stepping the issue of legal parentage. In that case, the Full Court of the Family Court noted in a single line that the surrogate mother and commissioning father were the registered parents of the child, did not comment on the fact that this was not in accordance with either state law or the Family Law Act itself (both of which ascribed parental status to the surrogate's husband) ${ }^{82}$ and at no stage appeared to consider a declaration as to parentage. While the contentious issue was residence of the child, remarkably the trial court ordered that the commissioning

\footnotetext{
${ }^{81}$ A number of US regimes are similarly limited: see discussion in Storrow, 2002, 643-644. Note that amendments currently before UK parliament would, if passed, extend the provisions considerably, including both civil partners and couples 'who are living as partners in an enduring family relationship': Human Fertilisation and Embryology Bill 2007 (UK) $\mathrm{Cl} 54$

${ }^{82}$ At trial the issue was discussed at greater length because the Ss claimed legal parentage, however this claim was swatted away by the judge as a "legal fiction" which was subsumed by the best interests approach: see discussion in Otlowski 1999, 52-54.
} 
couple and birth parents all share parental responsibility for the long term welfare, care and development of the child - in a very real sense creating four parents - and this part of the decision was not appealed.

The facts of Re Evelyn also contrast with those of many US surrogacy disputes; it was an "altruistic" arrangement between mature adults who were long-term friends, Mrs and Mr S, and Mrs and Mr Q. Mrs S was both the gestational and genetic mother while Mr Q was the genetic father. Mr and Mrs S had three children, while the Qs were infertile as a result of Mrs Q having had ovarian cancer and in the year or two prior to the birth of Evelyn they had adopted a son of Aboriginal descent, Tom. It was the gestational mother, Mrs S, who initiated the arrangement and repeatedly pursued it in the face of ambivalence from the Qs. Perhaps most importantly, Evelyn lived with the Qs for more than six months before Mrs S removed the child from their care and claimed residence. Evelyn was returned to the Qs care through interim orders and stayed with them for a further six months pending trial. By the time of the appeal Evelyn was 18 months old and had lived with the Qs all her life. However the court ordered residence transferred to the Ss, with four days per month contact to the Qs.

Re Evelyn is a distinctly atypical surrogacy dispute because it did not take place until the child had been living with the commissioning parents for a considerable period of time. For that reason I acknowledge that broad conclusions cannot be drawn from it and applied to other surrogacy disputes. In my view, a child's best interests analysis that properly valued stability of attachment under current law should have dictated that Evelyn remain with the Qs. I would also suggest that, consistently with the model for consensual transfer of status discussed above, a time-lag of over six 
months after having relinquished the child should be enough to vitiate the ability of the gestational mother to change her mind.

Commentators received Evelyn positively because it affirmed the child's best interests principle in surrogacy as in all other child-related disputes, and because it stated that there was no preference in law for biological parents (Otlowski 1999; Stuhmcke 1998). Yet the trial decision in Evelyn is extremely problematic in its construction of the "naturalness" of biological family and, while some aspects of the reasoning were criticised by the Full Court of the Family Court of Australia, the decision was not disturbed on appeal. The trial court held that Evelyn would "find residence in her mother's home as a more natural situation".83 The judgment also featured a series of passages contrasting the home of Evelyn's biological father with that of her biological mother, such as:

\begin{abstract}
In pure mathematical terms [residing with the Ss] she would have ready access to five of the eight most significant people in her life...I have concluded that, on balance, a child in Evelyn's situation is more likely to cope readily with the prospect of being required to visit the home of her biological father and step-brother from the comfort of the home of her biological mother and two biological sisters and one biological brother, than she would on the alternate outcome. 84
\end{abstract}

The pre-eminence of biology in this passage is pervasive and un-rationalised. Firstly it is notable that Evelyn's current home is characterised as that of her "biological father"

- her social mother and primary caregiver, Mrs Q, is completely absent, and Tom is described erroneously as a "step-brother". 85 A linguistic sleight of hand transforms Evelyn's genetic half-siblings into "biological" siblings, who are moreover assumed to

\footnotetext{
${ }^{83}$ Re Evelyn (1998) FLC 92-807 at 85106.

${ }^{84}$ Id at 85105 .

${ }^{85}$ Tom would be Evelyn's step-brother if he were the biological or adopted child of Mrs Q but not Mr Q, as a step-child is a relation by reason of the marriage of one's parent. Evelyn is the biological child of Mr Q and Tom is his child by adoption, so they are arguably half-siblings.
} 
be among the most important people in her life although she has not yet met them. The next paragraph continues with the finding that the "loss of the opportunity to be raised with her biological siblings is a greater loss than likely to be occasioned if she is now separated from Tom" and is followed by repeated declarations that the relationship of biological siblings is "special" and "cannot be replicated" by adopted siblings. ${ }^{86}$ Mrs S offers biological connection - and lots of it, more than the Qs ever can (because they are, after all, infertile).

The Qs are here placed in a position similar to that of a lesbian co-mother in intra-lesbian disputes over children, where their history of care for the child evaporates in the face of the biological mother's position as the "natural" parent. The reference to "mathematical terms" in deciding the importance of Evelyn's future family relationships echoes a passage of the judgment of the House of Lords in the English intra-lesbian case of Re G which suggested that a biological mother is always 'more' of a mother than a social parent can be. In Re G the court accepted that parents in nontraditional families may be genetic, gestational or social/psychological, but went on to characterise the birth mother as "the natural mother of these children in every sense of that term" 87 and "both their biological and their psychological parent" 88 , while the co-mother, like an adoptive parent, could only ever be a psychological parent. In a recent critique of Re G, Alison Diduck argues that biological connectedness is seen as such an unquestioned good that it is not a factor additional to a child's best interest or welfare inquiry but is rather fused with it. Diduck states, "Biological relationships ...

\footnotetext{
${ }^{86}$ Re Evelyn (1998) FLC 92-807 at 85106.

${ }^{87}$ Re G [2006] 4 All ER 241 para 44 (emphasis added).

${ }^{88}$ Id para 37 (emphasis added).
} 
take priority, in the name of welfare, over social ones" (Diduck, 2007, emphasis in original) - a remark equally applicable to the court's approach in Re Evelyn.

There are also a number of resonances between Re Evelyn and lesbian mother versus donor disputes. In Re Evelyn the trial court came to the empathic conclusion that "Evelyn will suffer problems relating to issues such as abandonment and identity during her adolescence" 89 (and held that her biological mother would be most able to help her through these hypothetical problems). This conclusion was based on the evidence of experts for the Ss, whose views were drawn from adoption literature.90 A great deal of literature on adopted children, like that of children conceived through donor gametes, is based on the experiences of people who were not told about their origins as children and so experienced feelings of shock, deception or betrayal by their parents when they found out later in life (McNair 2004, 39-45; Haimes 1998). Such research is not necessarily applicable, or even relevant, to families formed through surrogacy or donor gametes where children are told the truth about their conception from the outset. (Note also that research into children being raised in families formed through surrogacy is only just beginning: see eg Golombok et al 2006). Yet speculative opinions drawn from this body of knowledge were utilised in Re Evelyn to find as a certainty that Evelyn would suffer problems later in life as a result of the circumstances of her conception. It is not difficult to see how such speculative misapplication of research about genetic connection could play out in many other cases involving families formed through the use of donor gametes. Similarly, in the

\footnotetext{
${ }^{89}$ Re Evelyn (1998) FLC 92-807 at 85103 (emphasis added).

${ }^{90}$ The Qs attacked the validity of such comparisons on appeal, leading the Full Court to note that in fact one of the experts had drawn his views more from foster care (85107), arguably an even less appropriate analogy.
} 
long-running sperm donor versus lesbian mother case of $\mathrm{P} v \mathrm{~K}$ in New Zealand, ${ }^{11}$ the court relied upon child development research regarding the benefits of an on-going relationship with biological parents drawn from a completely different context (separated heterosexual families) to support a finding which superimposed a biological father onto an intact functioning lesbian family. In such instances it seems that the (mis)use of research may be a pretext for the projection of 'commonsense' notions that seek to recreate genetic families in the face of contradictory experience.

Another issue in Re Evelyn was the Qs' attitude to contact. The Ss proposed liberal contact with the Qs should they have residence, whereas the Qs "expressed reservations" about contact between the Ss and Evelyn should Evelyn live with them. ${ }^{2}$ In a 'pro-contact' family law culture which places great emphasis on biological relationships, the Ss' attitude to contact bolstered their claim, while the Qs' attitude harmed theirs. Yet the Qs' concern that it would be undermining for Tom's sense of stability and attachment to see his sister treated differently to him based on genetics (especially given that it seems he was the only non-white member of the family), was never seriously entertained. The Qs felt that extensive contact threatened them as a family unit, whereas the court characterised contact as simply maintaining Evelyn's family relationships.93 The Qs' concerns about an absent biological parent undermining their sense of family are strongly resonant of lesbian-led families' disputes with biological fathers. Lesbian mothers have at times opposed contact between sperm donors and children on the basis that his self-concept as a 'father' was

\footnotetext{
${ }^{91}$ P v K [2006] NZLR 22.

${ }^{92}$ Re Evelyn (1998) FLC 92-807 at 85097.

93 "The Ss would like to have Evelyn taken to South Australia to enable the siblings to enjoy contact together": Id at 85098 .
} 
undermining their family unit, confusing to the child, and necessitated unequal treatment of siblings based on genetic links when families were formed with different donors.94 Courts have been overwhelmingly dismissive of such concerns, have 'naturalised' the role of donors as fathers and have characterised biological fathers as inevitably adding to rather than intruding on or undermining lesbian family units (Millbank 2008b).

While in lesbian mother versus sperm donor cases, fathers' rights discourses and genetic essentialism flow seamlessly into one another to transform the role of biological fathers from gamete donors into bedrock social relationships of unquestioned benefit to children, Re Evelyn shows that genetic essentialism does not always benefit fathers. Ideas of genetic truth and the importance of genetic relationships to children do not stand alone; rather they are played out in the midst of other pre-existing conceptions of gender roles and family forms, which will sometimes reinforce and other times cut across them. For example, the modern context of family law in which a 'normal' father-child relationship commonly entails a non-resident father, may make the decisions in Evelyn and in $\mathrm{P} v \mathrm{~K}$ seem more like the maintenance of a 'normal' cultural status quo to courts (biological or 'natural' fathers being granted beneficial contact with their children) rather than a dramatic breach and judicial refashioning of established relationships for the non-traditional families in question.

\section{Conclusion}

\footnotetext{
${ }^{94}$ See eg. Thomas S v Robin Y 618 NYS2d 356 (1994); 599 NYS2d 377 (1995); Re D [2006] EWHC 2; P v K [2006] NZLR 22.
} 
These case studies highlight the competing place of social and genetic parenthood. By and large the decisions document the pervasiveness of biological understandings of family and illustrate a powerful contemporary trend in family law to transpose ideas of 'genetic truth' into actual social relationships. In Evans, the coalescence between the imposed 'need' for fathers in reproductive technology regulation with assumptions that any genetic connection is actually parenthood utterly thwarted Natalie Evans' parental aspirations. In Re Evelyn the court assumed that separation from a biological mother was akin to the 'abandonment' of adoption and would cause long-term problems for a baby, while separation from her social mother/primary caregiver was viewed as less significant. These cases evidence Alison Diduck's argument that there has been a "shift in the relative importance of biological relationships over social ones" in family law in which genetic 'truth' has been enmeshed with both the discourse of children's welfare and that of children's rights (Diduck 2007). In Re. R, the court was confounded by the paradox of a willing (yet non-consenting) father who had no genetic link to the child. Although denied parental status, Mr B was nonetheless characterised as a holder of 'genetic truth' in the face of the mother's deceit surrounding conception, and he was granted indirect contact to ensure, among other things, that the child was informed of her "unusual biological background" and helped to "come to terms with her origins". 95

Unlike most family law determinations, the cases under discussion here concern families formed by intention rather than by genetics alone. In addition, the cases all involve parties with parental claims who are not in relationships with each other or living in common households, and all concern very young children or embryos. Judges looking to, or for, ideas of 'traditional' family relationships in this

\footnotetext{
${ }^{95}$ Re R [2001] 1 FLR 247 para 13, see discussion in Sheldon 2005b.
} 
context is mere fantasy. Reflective empathy may play an important role in such disputes, drawing attention to whose position is identified with and opening a more thoroughgoing investigation into what interests are valued, and why they are valued. Empathy may not provide 'the answer', but it should generate more nuanced questions that are pursued in a context-sensitive rather than abstract fashion. Being mindful of empathy in an evaluative inquiry may also take us beyond the oppositional binaries that adversarial dispute resolution so often engenders. In the Evans and Re. R cases in particular, I argue that empathy should take us behind the parties' individual positions in the dispute to ask how those positions were first moulded by social and legal conditions, and urge us to seek more creative resolution. In Re Evelyn I find strong resonances with the position of a heterosexual commissioning couple in a surrogacy arrangement and the experiences of lesbian families.

Cultural narratives of genetic essentialism are in the ascendant and I suggest that this augers very ill for non-biological families formed with the use of donor gametes. In this light it may well be important for 'reproductive outsiders' of all kinds to recognise and draw on their commonalities, while being respectful too of differences, in order to work for a legal regime that can fully accommodate both their parental aspirations and functional parent-child relationships. 


\section{ACKNOWLEDGMENTS}

My thanks to Tiffany Hambley, Anita Stuhmcke and Lesley Townsley for their comments on earlier drafts, as well as on-going discussion of many of the ideas informing the paper, and to Kirsten Camarsh for her research assistance.

\section{REFERENCES}

Almack, Kathryn. 2005. What's in a name? The significance of the choice of surnames given to children born within lesbian-parent families. Sexualities 8: 239-254.

Almack, Kathryn. 2006. Seeking sperm: Accounts of lesbian couples' reproductive decision-making and understanding of the needs of the child. International Journal of Law, Policy and the Family 20/1: 1-22.

Appleton, Susan F. 2006. Presuming women: Revisiting the presumption of legitimacy in the same-sex couples era. Boston University Law Review 86: 227-294.

Bender, Leslie. 2006. "To err is human": ART mix-ups: a labor based, relational proposal. Journal of Gender, Race and Justice 9/3: 443-508.

Boyd, Susan. 2006. Robbed of their families? Fathers' rights discourses in Canadian parenting law reform processes. In Fathers' rights activism and law reform in comparative perspective, ed. Richard Collier and Sally Sheldon, 27-52. Oxford: Hart.

Cahn, Naomi R. 1997. Reframing child custody decisionmaking. Ohio State Law Journal 58: 1-60.

Cahn, Naomi R. 2002. Parenthood, genes and gametes: The family law and trusts and estates perspectives. University of Memphis Law Review 32: 563-606.

Chrisafis, Angelique. 2006. Parenthood postponed. The Guardian, 20 February. Collier,

Richard, and Sally Sheldon, eds. 2006. Fathers' Rights Activism and Law

Reform in Comparative Perspective. Oxford: Hart.

Crowley, Jocelyn E. 2006. Adopting 'Equality Tools' from the toolboxes of their predecessors: The fathers' rights movement in the United States. In Fathers' Rights Activism and Law Reform in Comparative Perspective, ed. Richard Collier and Sally Sheldon, 79-100. Oxford: Hart.

D’Arms, Justin. 2000. Empathy and evaluative inquiry. Chicago-Kent Law Review 74/4: 1467-1500.

Dempsey, Deborah. 2004. Donor, father or parent? Conceiving paternity in the Australian Family Court. International Journal of Law, Policy and the Family. 18/1:76-102.

Diduck, Alison. 2007. 'If only we can find the appropriate term to use this issues will be solved': Law, identity and parenthood. Child and Family Law Quarterly 19: 458. 
Dolgin, Janet L. 2000. Choice, tradition, and the new genetics: The fragmentation of the ideology of the family. Connecticut Law Review 32: 523-566.

Donovan, Catherine. 2000. Who needs a father? Negotiating biological fatherhood in British families using self-insemination. Sexualities 3:149-164.

Donovan, Catherine. 2006. Genetics, fathers and families: Exploring the implications of changing the law in favour of identifying sperm donors. Social and Legal Studies 15/4: 494-510.

Gavigan, Shelley. 2006. Equal families, equal parents, equal spouses, equal marriage: The case of the missing patriarch. Supreme Court Law Review 33: 317-342.

Golombok, Susan, MacCallum, Fiona, Murray, Clare, Lycett, Emma, and Jadva, Vasanti. 2006. Surrogacy families: Parental functioning, parent-child relationships and children's psychological development at age 2. Journal of Child Psychology and Psychiatry 47/2: 213-222.

Graycar, Reg. 2000. Law reform by frozen chook: Family law reform for the new millennium. Melbourne University Law Review 24/3: 737-755.

Haimes, Erica. 1998. The making of 'the DI child': Changing representations of people conceived through donor insemination. In Donor insemination: International social science perspectives, ed. Kenneth Daniels and Erica Haimes, 53-75. Cambridge: Cambridge University Press.

Henderson, Lynne N. 1987. Legality and empathy. Michigan Law Review 85/7: 15741653.

Jones, Caroline. 2005. Looking like a family: Negotiating bio-genetic continuity in British lesbian families using licensed donor insemination. Sexualities 8/2: 221-237.

Kaspiew, Rae. 2005. Violence in contested children's cases: An empirical exploration. Australian Journal of Family Law 19: 112-143.

Kaye, Miranda, Stubbs, Julie and Tolmie, Julia. 2003. Domestic violence and child contact arrangements. Australian Journal of Family Law 17: 93-133.

Lessard, Hester. 2004. Mothers, fathers, and naming: Reflections on the law equality framework and Trociuk v British Columbia (Attorney General). Canadian Journal of Women and the Law 16: 165-211.

Lind, Craig. 2003. Re R (Paternity of IVF Baby): Unmarried paternity under the Human Fertilisation and Embryology Act 1990. Child and Family Law Quarterly 15/3: 327-340.

Lind, Craig. 2006. Evans v United Kingdom - Judgments of Solomon: Power, gender and procreation. Child and Family Law Quarterly 18: 576-592.

McNair, Ruth. 2004. Outcomes for children born of ART in a diverse range of families. Occasional Paper, Melbourne: Victorian Law Reform Commission. 
Millbank, Jenni. 2006. Recognition of lesbian and gay families in Australian law - Part two: Children. Federal Law Review 34: 205-260.

Millbank, Jenni. 2008a. The role of 'functional family' in same-sex family recognition trends. Child and Family Law Quarterly 20/2: 155-182.

Millbank, Jenni. 2008b forthcoming. The limits of functional family: Lesbian mother litigation in the era of the eternal biological family. International Journal of Law, Policy and the Family 22/2.

Millbank, Jenni. 2003. And Then ... The Brides Changed Nappies. Available on ssrn.com.

Minter, Shannon and Kendall, Kate. 2000. Beyond second-parent adoption: The Uniform Parentage Act and the "Intended Parents" - A model brief. Georgetown Journal of Gender and the Law 2: 29-56.

Nussbaum, Martha C. 2001. Upheavals of Thought. New York: Cambridge University Press.

Otlowski, Margaret. 1999. Re Evelyn - Reflections in Australia's first litigated surrogacy case,. Medical Law Review 7/1: 38-57.

Polikoff, Nancy D. 1996. The deliberate construction of families without fathers: Is it an option for lesbian and heterosexual mothers. Santa Clara Law Review 36/2: 375394 .

Polikoff, Nancy D. Breaking the link between biology and parental rights in planned lesbian families: When semen donors are not fathers. Georgetown Journal of Gender and the Law 2: 57-90.

Rhoades, Helen. 2006. Yearning for law: Fathers' groups and family law reform in Australia. In Fathers' Rights Activism and Law Reform in Comparative Perspective, ed. Richard Collier and Sally Sheldon, 125-146. Oxford: Hart.

Rothman, Barbara K. 1992. Reproductive technologies and surrogacy: A feminist perspective. Creighton Law Review 25/5: 1599-1615.

Seymour, John and Magri, Sonia. 2004. ART, surrogacy and legal parentage: A comparative legislative Review. Melbourne: The Victorian Law Reform Commission.

Shapiro, Julie. 2006. A lesbian centered critique of Genetic Parenthood. Journal of Gender, Race and Justice 9/3: 591-612.

Sheldon, Sally. 2001. 'Sperm Bandits', birth control fraud and the battle of the sexes. Legal Studies 21/3: 460-480. 
Sheldon, Sally. 2004. Gender equality and reproductive decision-making. Feminist Legal Studies 12/3: 303-316.

Sheldon, Sally. 2005a. Reproductive technologies and the legal determination of fatherhood. Feminist Legal Studies 13/3: 349-362.

Sheldon, Sally. 2005b. Fragmenting fatherhood: The regulation of reproductive technologies. Modern Law Review 68/4: 523-553.

Smart, Carol. 1991. The legal and moral ordering of child custody. Journal of Law and Society 18/4: 485-500.

Smart, Carol. 1995. Losing the struggle for another voice: The case of family law. Dalhousie Law Journal 18: 173-195.

Smart, Carol. 2006. The ethic of justice strikes back: Changing narratives of fatherhood. In Feminist perspectives on family law, ed. Alison Diduck and Katherine O’Donovan, 123-138. London: Routledge.

Snyder, Steven H. and Byrn, Mary P. 2005. The use of pre-birth parentage orders in surrogacy proceedings. Family Law Quarterly 39/3: 633-662.

Storrow, Richard F. 2002. Parenthood by pure intention: Assisted reproduction and the functional approach to parentage. Hastings Law Journal 53/3:597-679.

Stuhmcke, Anita. 1998. Re Evelyn: Surrogacy, custody and the Family Court. Australian Journal of Family Law 12: 297-304.

Stuhmcke, Anita. 2004. Looking backwards, looking forwards: Judicial and legislative trends in the regulation of surrogate motherhood in the UK and Australia. Australian Journal of Family Law 18: 13-40.

Young, Claire and Boyd, Susan. 2006. Losing the feminist voice? Debates on the legal recognition of same sex partnerships in Canada. Feminist Legal Studies 14/2: 213240.

Waldman, Ellen. 2004. The parent trap: Uncovering the myth of "Coerced Parenthood" in frozen embryo disputes. American University Law Review 53/5: 10211062. 